5. Директива Ради СС від 12 червня 1986 року про захист навколишнього середовища та, зокрема, грунту у випадках використання у сільському господарстві осаду стічних вод (86/278/СС) - Документ Мінюсту Україні 19861-278- UA - 05 - 06. 003.001.

6. Ковальчук В. А. Очистка стічних вод.- Рівне: ВАТ “Рівненська друкарня,"2002, 622 с.

7. Лосева Я.П., Мищенко Я.В., Гриванова С.М. Эффективность рассеивания испарений от резервуаров канализационных очистных сооружений города Владивостока. - Фундаментальные исследования. 2013. - № 11 (часть 7) - С. 1383-1388.

8. Liu, Y., and Fang, H. (2002) Extraction of extracellular polymeric substances (EPS) of sludges. J Biotechnol, 95, 249-56.

9. S.H. Hansen, A. Stensballe, P.H. Nielsen,F.-A. Herbst - Metaproteomics: Evaluation of protein extraction from activated sludge. // PROTEOMICS. Volume 14, Issue 21-22 November 2014 Pages 2535-2539.

10. Leybovych L.I., Patsurkovskiy P.A. Influence of salinity of water on purification of air from hydrogen sulfide in contact devices. - Magazine of Academia o science of Moldova. Institute of power engeneering "Problem of the regional energetics", 3 (29), 2015 - p. 80-88.

11. Евилевич А.3. Осадки сточных вод. Удаление, обработка, использование. - Стройиздат. Ленинград. 1965 - 324 с.

\title{
ЦИТ: иа117-076
}

DOI: 10.21893/2415-7538.2016-06-5-076

УДК 577.112:633.11:631.8

Кудрявицька А.М.

ВПЛИВ ТРИВАЛОГО ЗАСТОСУВАННЯ ДОБРИВ НА ФРАКЦІЙНИЙ СКЛАД БІЛКУ ОЗИМОЇ І ЯРОЇ ПШЕНИЦІ ТА ПОКАЗНИКИ ЯКОСТІ

Наиіональний університет біоресурсів і природокористування України Київ, Героїв оборони, 1503041

Kudriawitska A.N.

INFLUENCE OF THE PROTRACTED APPLICATION OF FERTILIZERS IS ON FACTIOUS COMPOSITION OF ALBUMEN OF WINTER AND SPRING WHEAT AND INDEXES OF QUALITY

National university of life and environmental sciences of Ukraine Kyiv, Heroes of Defensive, 1503041

Анот ація. При т ривалому заст осуванні добрив на лучно-чорноземному карбонат ному грубопилуват о-легкосуглинковому на лесовидному суглинку грунт $і$ спост ерігаєт ься підвищення вміст у проламінів т а глют елінів в зерні озимої і ярої пшениці. Найбільші коливання відмічені у вміст і проламінів, а найменші-у вміст і альбумінів т а глобулінів.

Ключові слова: якіст ь зерна, білок, фракційний склад, добрива, грунт .

Abstract. At long application of fertilizers on meadow chernozem to ground increase of the contents polyamines and glutens in a grain winter and spring wheat is 
marked. The greatest fluctuations are marked in the contents polyamines, and least the contents albumins and globulins.

Key words: productivity, fractional structure, fertilizers, soil.

Дослідженнями вчених встановлено, що застосування добрив суттєво змінює фракційний склад білків в зерні пшениці [1-4]. При внесенні азотних добрив відбувається зміна співвідношень білкових фракцій в зерні: підвищується вміст запасних білків(головним чином проламінів), зменшується вміст альбумінів і глобулінів [5-6].

Результати досліджень

Вміст водорозчинної та солерозчинної фракції білків озимої пшениці коливається в межах 0,39-0,51\% (табл. 1). Відбувається підвищення вмісту проламінів та глютенінів. На варіанті $\mathrm{N}_{110} \mathrm{P}_{120} \mathrm{~K}_{120}$ на фоні післядії органічних добрив вміст проламінів складає 0,82\%, що на $0,26 \%$ більше по порівнянню 3 контролем. Найбільший вміст лугорозчинної фракції відмічений на варіанті $\mathrm{N}_{110} \mathrm{P}_{120} \mathrm{~K}_{120}$, який становить $0,61 \%$, з відповідним вмістом на контролі-0,42\%.

Вміст водорозчинної та солерозчинної фракції білків ярої пшениці коливається в межах 0,36\%-0,48\% (табл.2.). Найбільші коливання відмічені у вмісті проламінів. Так, на варіанті $\mathrm{N}_{110} \mathrm{P}_{120} \mathrm{~K}_{120}$ на фоні післядії органічних добрив відмічено найвищий вміст білків, які утворюють клейковину: проламінів- $0,85 \%$ та глютенінів- $0,64 \%$ відповідно.

Таблиця 1

Вплив тривалого застосування добрив на фракційний склад білку озимої пшениці, \%

\begin{tabular}{|c|c|c|c|c|c|}
\hline \multirow[b]{2}{*}{ Варіант досліду } & \multirow[b]{2}{*}{ Білок, \%; } & \multicolumn{4}{|c|}{ Фракції азоту, \% } \\
\hline & & $\begin{array}{l}\stackrel{0}{0} \\
\text { in } \\
\text { in }\end{array}$ & 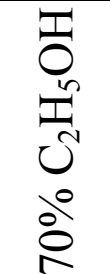 & 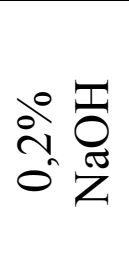 & 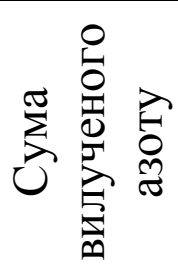 \\
\hline Контроль & 9,2 & 0,39 & 0,56 & 0,42 & 1,37 \\
\hline $\begin{array}{c}\text { Післядія 30т/га } \\
\text { гною-Фон }\end{array}$ & 11,6 & 0,44 & 0,59 & 0,48 & 1,51 \\
\hline$\Phi \mathrm{OH}+\mathrm{P}_{80}$ & 11,9 & 0,45 & 0,62 & 0,51 & 1,58 \\
\hline$\Phi \mathrm{OH}+\mathrm{P}_{80} \mathrm{~K}_{80}$ & 12,1 & 0,46 & 0,64 & 0,53 & 1,63 \\
\hline$\Phi$ OH $+\mathrm{N}_{80} \mathrm{P}_{80} \mathrm{~K}_{80}$ & 12,4 & 0,49 & 0,68 & 0,56 & 1,73 \\
\hline$\Phi$ oH $+\mathrm{N}_{110} \mathrm{P}_{120} \mathrm{~K}_{120}$ & 12,7 & 0,51 & 0,82 & 0,61 & 1,94 \\
\hline $\mathrm{N}_{80} \mathrm{P}_{80} \mathrm{~K}_{80}$ & 12,1 & 0,47 & 0,66 & 0,55 & 1,68 \\
\hline
\end{tabular}

Висновки. При тривалому застосуванні добрив в складі білку зерна озимої та ярої пшениці більше змінюється вміст білків, які утворюють клейковину причому в більшому ступені змінюється вміст проламінів. При дозріванні зерна озимої та ярої пшениці відносний вміст альбумінів i легкорозчинних глобулінів значно зменшується, кількість проламінів і глютелінів різко підвищується. 
Таблиця 2

Вплив тривалого застосування добрив на фракційний склад білку ярої пшениці, \%

\begin{tabular}{|c|c|c|c|c|c|}
\hline \multirow[b]{2}{*}{ Варіант досліду } & \multirow[b]{2}{*}{ Білок, \%; } & \multicolumn{4}{|c|}{ Фракції азоту, \% } \\
\hline & & 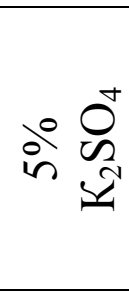 & 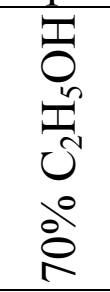 & 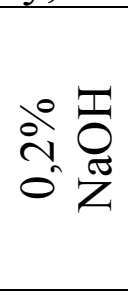 & 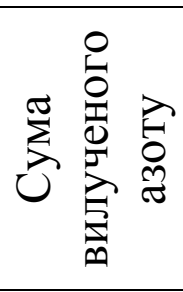 \\
\hline Контроль & 14,8 & 0,36 & 0,6 & 0,43 & 1,39 \\
\hline $\begin{array}{l}\text { Післядія 30т/га } \\
\text { гною-Фон }\end{array}$ & 16,4 & 0,4 & 0,62 & 0,49 & 1,51 \\
\hline$\Phi_{\mathrm{OH}}+\mathrm{P}_{80}$ & 16,0 & 0,42 & 0,64 & 0,53 & 1,59 \\
\hline$\Phi$ oH $+\mathrm{P}_{80} \mathrm{~K}_{80}$ & 16,5 & 0,46 & 0,65 & 0,57 & 1,68 \\
\hline$\Phi \mathrm{OH}^{+} \mathrm{N}_{80} \mathrm{P}_{80} \mathrm{~K}_{80}$ & 16,7 & 0,47 & 0,79 & 0,59 & 1,85 \\
\hline$\Phi$ оH $+\mathrm{N}_{110} \mathrm{P}_{120} \mathrm{~K}_{120}$ & 17,2 & 0,48 & 0,85 & 0,64 & 1,97 \\
\hline $\mathrm{N}_{80} \mathrm{P}_{80} \mathrm{~K}_{80}$ & 16,7 & 0,46 & 0,78 & 0,57 & 1,81 \\
\hline
\end{tabular}

Література:

1. Новиков Н.Н. Белки зерна пшеницы и формирование качества урожая: Автореф. дис. д-ра биол. наук. М., 1995. 62 с.

2. Ерошенко, Ф.В. Особенности фотосинтетической деятельности сортов озимой пшеницы / Ф.В. Ерошенко. Ставрополь, 2006. - 198 с.

3. Иванов Н.Н. Методы физиологии и биохимии растений. М.-1968.-128 с.

4. Мосолов И.В., Воллейдт Л.В. Влияние доз, соотношения азота и фосфора на обмен веществ, урожай и качество зерна ярой пшеницы.Физиология растений.-т.9.-№2.-1962.-С. 45-57.

5. Княгиничев М.И. Биохимия пшеницы.-М.-1951.-205 с.

6. Кудзин Д.К., Мельниченко В.Ф. Влияние отдельных приемов на белковость зерна пшеницы в условиях степи УССР.- Сб.: Вопросы улучшения качества с.-х. Продукции.-Вып.1.-К.:1960.-С. 20-33.

Стаття відправлена: 09.06.2017 p.

(C) Кудрявицька A.M.

\section{ЦИТ: иа117-077}

DOI: 10.21893/2415-7538.2016-06-5-077

626.87:631.432.1

Мозоль Н.В.

МОДЕРНІЗАЦІЯ ДРЕНАЖНИХ СИСТЕМ ПРИ РЕГУЛЮВАННІ ВОДНОГО РЕЖИМУ ОСУШУВАНИХ ЗЕМЕЛЬ

Інститут водних проблем і меліорачії НАAН

Київ, вул. Васильківська 37, 03022 